\title{
Effect of the Rhizospheric Micro-organisms of Some Fabaceaes and Peat Substratum on the Growth of Carob Tree (Ceratonia siliqua L.)
}

\author{
Youcef Dalli $^{1}$, Noureddine Yahia ${ }^{1}$, Seghir Hadjadj-Aoul ${ }^{2} \&$ Abdelkader Bekki $^{1}$ \\ ${ }^{1}$ Laboratoire de Biotechnologie des Rhizobia et Amélioration des Plantes, Département de Biotechnologie, \\ Université Oran1, Oran, Algeria \\ ${ }^{2}$ Laboratoire d'Ecologie, Département de Biologie, Université Oran1, Oran, Algeria \\ Correspondence: Youcef Dalli, Laboratoire de Biotechnologie des Rhizobia et Amélioration des Plantes, \\ Département de Biotechnologie, Université Oran1, BP 1524, El Menaour, Oran, Algeria. Tel: 213-556-996-560. \\ E-mail: youcef_dalli@hotmail.com
}

Received: July 2, 2019 Accepted: August 7, $2019 \quad$ Online Published: October 15, 2019

doi:10.5539/jas.v11n17p86 URL: https://doi.org/10.5539/jas.v11n17p86

\begin{abstract}
Intensive exploitation of sand quarry sites inevitably results in near total destruction of plant cover and soil degradation. The damage done is so important that without human intervention, soil scarification and vegetable return to growth may take several decades. In order to conduct a site rehabilitation programme successfully reforestation through the plantation of a native species such as the carob tree (Ceratonia siliqua) should be the appropriate choice. Because of their facilitation effect, the spontaneous leguminous plants present in the site, specifically Lotus creticus, Retama monosperma and L. creticus associated with R.monosperma can be used as nurse plants. Our assumption is that they possess a rhizosphere rich in microorganisms, which may positively impact the growth of carob. To this end, a study is conducted in order to: a) estimate the diversity of arbuscular mycorrhiza fungi (AMF) living underneath the spontaneous leguminous plants of the site; b) determine their combined effect with other microsymbionts (i.e., total bacteria and actinobacteria) on the growth of the carob tree; c) draw a comparison with carob grown in bare soil and in sterile soil mixed with peat regarding its growth parameters and mineral nutrition. The trees were grown in plastic pots under greenhouse conditions and, after 12 months, the results have shown that, against all odds, the soils of $R$. monosperma and $L$. criticus associated with $R$. monosperma do not significantly influence the growth of the tree whereas the impact of the soil of $L$. creticus is outright negative. On the other hand, peat improves the root and aerial growth of the tree, which shows in leaves number, branch number and capacity of nutrition in nitrogen. Because a little richer in actinobacteria, bare soil increases the length of the aerial parts and improves the tree's phosphorus uptake.
\end{abstract}

Keywords: leguminous plants, microsymbionts, mycorrhizae, plant associations, reforestation strategy

\section{Introduction}

After water, sand is the second most consumed resource worldwide: 400 billion tons a year. It represents a trading volume of 70 billion dollars a year, 56 million tons of which are consumed in Algeria, mainly used in the building and construction sector (Denis, 2013; Richer, 2018).

Sand extraction in quarries leads to the loss of plant cover, and without human intervention in those damaged zones, vegetation is in the incapacity to regenerate itself. Moreover, the early phases of any healing process in these quarries would take many decades if not many centuries (Khater, 2004; Le Roux, 2002). The damage caused by sand extraction facilitates water and wind erosion which manifests itself as an alteration of the soils' physical, chemical and biological properties (Albaladejo et al., 1988; Tuo et al., 2018).

The introduction of the carob tree, a plant of socio-economic value, well- adapted to the soil and climatic conditions of the area is an essential prerequisite for the achievement of any soil restoration program, even more so as annual rainfall has become rare or irregular with long dry summer periods combined with anthropic pressure (Ait Chitt et al., 2007; Makhzoumi, 1997).

The carob tree is a plant originating in the Mediterranean region. It is of utmost interest from both an environmental and socio-economic perspectives (Batlle \& Tous, 1997). It is used in landscape ornamentation and valorization as a shady tree and in revegetation programs. It has persistent foliage and high quality wood, 
tolerates poor and degraded soils and produces an edible fruit: the carob. Many useful products are derived from the fruit. Carob flour is especially used in agro-food industry, in industrial confectionery production, alcohol processing through fermentation and as cocoa substitute. Carob tree gum is also used in agro-food, pharmaceutical, cinematographic, textile and cosmetic industries (Ait Chitt et al., 2007; Batlle \& Tous, 1997; Mahdad \& Gaouar, 2016).

The carob tree maintains associations with soil micro-organisms including mycorrhizae (Essahibi et al., 2017). Mutual-benefit association of different micro-organisms and the plant plays an important role in the conservation and development of natural terrestrial eco-systems and in the structure and diversity of vegetable communities as well as their survival (Bever et al., 2010; Brunel, 2006; Lozano, 2014).

In a degraded eco-system, shrubs and herbaceous species constitute spots of fertility because beneath their soils live rhizospheric microbiota that are able to promote and impact the survival of other native species as a result of their action as 'nurse plants' (Carrillo et al., 2000; Garner, 1989; Maestre et al., 2009) including bacteria and arbuscular mycorrhizal fungi (AMF) in particular (Susana et al., 2016). AMF play a major role in the forestry management programs and restoration of degraded soils (Duponnois et al., 2010).

The purpose of this task is: a) to test the effect on the growth of the carob tree in nursery of some spontaneous leguminous plants Retama monosperma, Lotus criticus and associated plants $R$. monosperma + L. creticus through their rhizospheric soils and by comparison with bare soil and sterile peat substrate; b) to study the diversity and distribution of the rhizospheric micro-organisms (AMF, bacteria) of these leguminous plants comparatively with bare soil and assess their role within the parameters relative to the growth of the carob tree; c) to promote the association or non-association of the carob tree with the spontaneous leguminous plant in revegetation programs.

\section{Materials and Methods}

\subsection{Site of Study and Sampling}

Our study has been conducted in a sand exploitation quarry at Terga which is located on the North-West coast of Algeria, 3526'33.03" North latitude and $1^{\circ} 13^{\prime} 33.48^{\prime \prime}$ West longitude, $85 \mathrm{~km}$ west of Oran (Figure 1). The region is characterized by a semi -arid mediterranean climate, around $405 \mathrm{~mm}$ per year rainfall and an average temperature of $18.5^{\circ} \mathrm{C}$. Random samples of rhizospheric soils and roots were collected during the year $2016 / 2017$ at a depth of $30 \mathrm{~cm}$ below 5 to 10 plants of $R$. monosperma, L. creticus and associated $R$. monosperma with L. creticus.
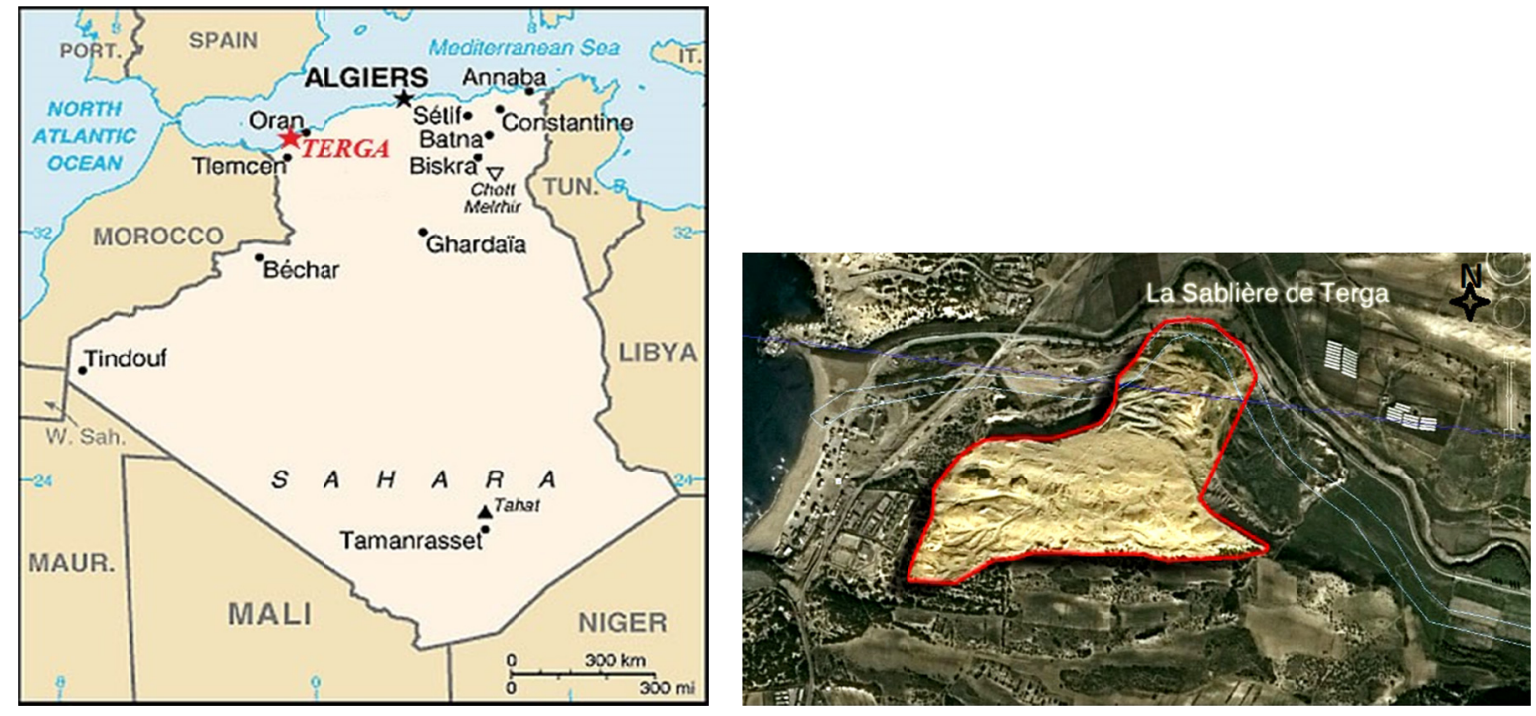

Figure 1. Geographic localization of Terga sand quarry sources:

(https://fr.wikipedia.org/wiki/Villes_d\%27Alg\%C3\%A9rie) and (https://www.google.fr/maps?hl=fr)

\subsection{Physical-Chemical Analyses of the Soil}

Physical-chemical analyses of the soil by characterization of granulometry was determined by series of siftings technique (AFNOR, 1990). Active lime proportion was determined as was described by Drouineau (1942). Total 
carbon and organic matter amounts were determined as was described by Anne (1945); $\mathrm{pH}$ and electrical conduction $(\mathrm{C})$ were measured using soil in suspension with $\mathrm{pH}$ and conductivity meters. Total nitrogen and available phosphorous levels were established following the method of Kjeldahl (1883) and Truog (1930) respectively.

\subsection{Root Coloring and Assessment of Mycorrhization Level}

Infection by AMF was observed after the coloration method described by Phillips and Hayman (1970) then observed under an optical microscope in order to determine the level of mycorrhization of the roots following Trouvelot et al. (1986).

\subsection{Spore Extraction, Enumeration and Morpho-anatomic Identification}

The spores are extracted from the rhizospheric soil using the wet sieving technique Gerdemann and Nicolson (1963), centrifuged in a sucrose solution to concentrate the spores then screened according to size, shape, color, attachment hyphae, number of layers before being observed through a binocular magnifier and enumerated. The results are expressed per $100 \mathrm{~g}$ of soil. The spores are mounted on slide and slip cover together with PVLG and/or Melzer reagent (Azcon-Aguilar et al., 2003) then observed under a photonic microscope. The spores are compared with the INVAM (2018) collection and the Glomeromycota taxonomy (Blaskowski, 2018) for morphologic identification.

\subsection{Bacterial Enumeration}

\subsubsection{Total Flora}

Soil samples are dried and sifted, the total bacteria are counted by the conventional method of dilution suspension in nutrient agar (Rapilly, 1968).

\subsubsection{Actinobacteria}

Soil samples are dried then mixed with $\mathrm{CaCO}_{3}, 1 \mathrm{~g}$ per $10 \mathrm{~g}$ of soil then incubated for 7 to 9 days at ambient temperature in an atmosphere saturated in moisture to reduce fungal flora (El-Nakeeb \& Lechevalier, 1963), then a treatment at $55^{\circ} \mathrm{C}$ to $100{ }^{\circ} \mathrm{C}$ is carried out for one hour to reduce the number of bacteria without affecting the number of actinobacteria (Agate \& Bhat, 1963). The actinobacteria are counted by the conventional method of suspension dilution in casein starch agar (CAA) added to fluconazole $(50 \mu \mathrm{g} / \mathrm{ml})$ (Sharma et al., 2011).

\subsection{Seed Scarification and Pre-germination}

The carob seeds are scarified in sulphuric acid $\left(95^{\circ}\right)$ for 90 minutes then rinsed several times in sterile water. The grains are placed in petri dishes containing 0.8 per cent agar water then incubated in the dark at $28{ }^{\circ} \mathrm{C}$ for germination.

\subsubsection{Cultivation}

Pre-germinated seeds are placed in pots with 5 seeds per pot containing rhizospheric soils of $R$. monosperma associated with $L$. creticus, $R$. monosperma, $L$. creticus, a sterile peat substrate $(3 / 4$ bare soil $+1 / 4$ peat) and a bare soil. Each treatment is repeated 5 times. The composition of the sterile peat reads as follows: M.O.: $47.9 \%$, pH: 7.12, $\mathrm{N}$ total: $20.5 \mathrm{mg} \mathrm{g}^{-1}, \mathrm{P}_{2} \mathrm{O}_{5}: 14.9 \mathrm{mg} \mathrm{g}^{-1}, \mathrm{~K}_{2} \mathrm{O}: 41.5 \mathrm{mg} \mathrm{g}^{-1}$. The plants are watered at a rate of 3 times a week with sterile distilled water. The experiment was conducted in a mini -greenhouse in natural conditions at an average temperature of $18.5^{\circ} \mathrm{C}$ and a level of humidity of $75 \%$.

\subsection{Growth Parameters}

The length of aerial and root parts is measured, the number of shoots and leaves counted and the fresh and dry weight of the aerial and root parts are determined. The foliar nitrogen content is determined by the Kjeldhal method (Rinaudo, 1970) and the phosphorus level by Olsen et al. (1954).

\subsection{Statistical Analysis}

All the different studied parameters were subject to principal component analysis (PCA) by using Statistica 6.0 software. PCA was carried out for grouping the treatments with growth and microbiological parameters.

\section{Results and Discussion}

\subsection{Soil Characterization}

Study of the soil structure shows that it is sandy, calcareous, alkaline, not salty, has a low CEC, and does not show significant difference between the samples. The soils are poor in organic matter with L. creticus and $L$. criticus $+R$. monosperma being the richest with rates of $0.12 \%$ and $0.14 \%$ respectively (Table 1 ). These results are characteristic of the dunes of West Algeria (Bouazza et al., 2015), close to those found in dune sites of 
Tunisian (Hatimi \& Tahrouch, 2007), and Spanish coasts (Camprubí et al., 2010), except for available phosphorus in which the soil is moderately rich to rich but poor in nitrogen. The highest levels are found in $L$. creticus soil. The rise of the level of available phosphorus is due to the nature of the mother rock or the activity of phosphate-solubilisating micro-organisms present in the soil such as AMF or PSB (phosphate solubilizing bacteria).

Table 1. Physical and chemical characterization of soils

\begin{tabular}{|c|c|c|c|c|c|c|c|c|c|c|c|c|c|c|c|}
\hline \multirow[b]{2}{*}{ Soils } & \multicolumn{6}{|c|}{ Granulometry } & \multirow{2}{*}{$\begin{array}{l}\mathrm{CaCO}_{3} \\
\text { Total } \\
(\%)\end{array}$} & \multirow{2}{*}{$\begin{array}{l}\text { Actif } \\
\mathrm{CaCO}_{3} \\
(\%)\end{array}$} & \multirow{2}{*}{$\begin{array}{l}\text { CEC } \\
(\mathrm{meq} / \\
100 \mathrm{~g})\end{array}$} & \multirow[b]{2}{*}{$\mathrm{pH}$} & \multirow{2}{*}{$\begin{array}{l}\text { C } \\
\text { (Emmhos/cm) }\end{array}$} & \multirow[b]{2}{*}{$\mathrm{C} \%$} & \multirow[b]{2}{*}{ O.M. } & \multirow{2}{*}{$\begin{array}{l}\mathrm{P}_{2} \mathrm{O}_{5} \\
(\mathrm{ppm})\end{array}$} & \multirow{2}{*}{$\begin{array}{l}\text { Total } \\
\mathrm{N} \%\end{array}$} \\
\hline & Gravel & $\begin{array}{l}\text { Coarse } \\
\text { sand }\end{array}$ & $\begin{array}{l}\text { Fine } \\
\text { sand }\end{array}$ & Silt & Clay & Texture & & & & & & & & & \\
\hline Lotus creticus & 0 & 78 & 9 & 9 & 2 & Sandy & 30.38 & 5.16 & 0.8 & 9.26 & 0.09 & 0.07 & 0.12 & 75.57 & 0.045 \\
\hline Retama monosperma & 0 & 91 & 8 & 0 & 0 & Sandy & 32.25 & 3.75 & 0.56 & 9.17 & 0.11 & 0.02 & 0.03 & 36.64 & 0.03 \\
\hline $\begin{array}{l}\text { L.creticus }+ \\
\text { R.monosperma }\end{array}$ & 0 & 83.6 & 10.2 & 5.6 & 0.6 & Sandy & 32.44 & 5.05 & 0.44 & 9.16 & 0.16 & 0.08 & 0.14 & 50.38 & 0.014 \\
\hline Bare soil & 0 & 95 & 4 & 0 & 0 & Sandy & 30.00 & 1.72 & 0.20 & 9.38 & 0.1 & - & 0.007 & 34.35 & 0.016 \\
\hline
\end{tabular}

\subsection{Root Colonization by AMF Innatura}

Microscopic observation of colorized roots proves their colonization by AMF with presence of vesicles and hyphae structures in the root cortex and absence of arbuscular structures for L. creticus and R. monosperma (Figure 2). There is no significant difference in the frequency of colonization F\% with a rate of $72 \%$ and $79 \%$ respectively. However, the intensity of the degree of colonization of $R$. monosperma is a little higher than that of L. certicus with $\mathrm{M} \%$ values $=35.51 \%$ and $12.4 \%$ respectively (Table 2 ). These results are inferior to those found by Benlhadj et al. (2016); Nehila et al. (2015) but similar to the work of Bouazza et al. (2015) as regards F\% frequency. Conversely, the intensity of $\mathrm{M} \%$ is superior for $R$. monosperma and inferior for L. criticus. This is probably due to the area and the season, but also the year of sampling (Bencherif et al., 2016).

Table 2. Mycorrhization rate; $\mathrm{F} \%$ : frequency of mycorrhization, $\mathrm{M} \%$ : intensity of root cortex colonization, $\mathrm{A} \%$ arbuscule abundance in the root system

\begin{tabular}{llll}
\hline Plants & $\mathbf{F \%}$ & $\mathbf{M \%}$ & $\mathbf{A \%}$ \\
\hline Lotus creticus & 72 & 12,4 & - \\
Retama monosperma & 79 & 35,51 & - \\
\hline
\end{tabular}
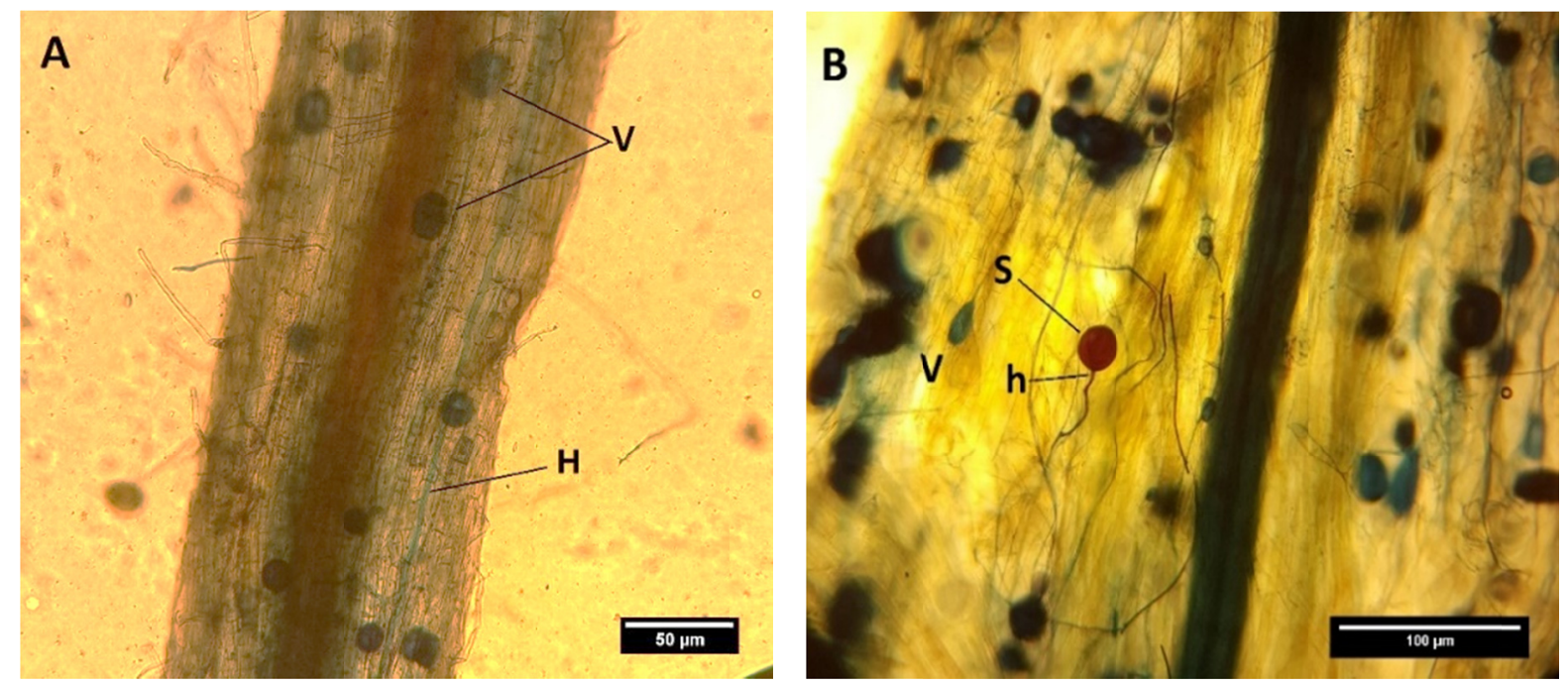

Figure 2. AMF structure in leguminous root plants in Terga site (in natura). A: AMF colonization in root cortex of L. creticus B: Root morphology of R.monosperma infected with AMF; (V: vesicles, H: mycorrhizal hyphae, S: spore, h: suspensor hyphae) (X40) 


\subsection{Sporal Diversity and Density}

The sporal count differs from a type of soil to another. L. creticus soil is the richest in number of spores $212 / 100$ $\mathrm{g}$; then comes association of $R$. monosperma soil and L. creticus with 102 spores/100 g, R. monosperma only with 85 spores/100 $\mathrm{g}$ whereas in bare soil the number of spores is less than 10 spores/100 $\mathrm{g}$ (Table 3). This number is inferior to the one found in the Algerian steppe and the Morrocan and Tunisian coastal regions (Belechheb et al., 2016; Bencherif et al., 2016; Mosbah et al., 2018). It is higher than the number recorded in the Spanish and Tunisian dunes according to the work of Camprubí et al. (2010); Hatimi and Tahrouch (2007).

Table 3. Enumeration and spore morphology characterization

\begin{tabular}{|c|c|c|c|c|c|}
\hline Rhizospheric soil & Spores Description & Spores Species & Size & Numbers/100 g soil & Total $/ 100 \mathrm{~g}$ soil \\
\hline \multirow{5}{*}{ Retama monosperma } & Dark brown & Glomus constrictum & $183 \pm 10 \mu \mathrm{m}$ & 21 & 85 \\
\hline & Brown & Acaulospora tuberculata & $156 \pm 10 \mu \mathrm{m}$ & 34 & \\
\hline & Small light brown & Glomus aggregatum & $60 \pm 20 \mu \mathrm{m}$ & 7 & \\
\hline & Brown subglobular & Non identified & $90 \pm 20 \mu \mathrm{m}$ & 22 & \\
\hline & Yellow & Claroideoglomus lamellosum & $136 \pm 5 \mu \mathrm{m}$ & 1 & \\
\hline \multirow{2}{*}{ Lotus creticus } & Brown & Acaulospora tuberculata & $155 \pm 20 \mu \mathrm{m}$ & 200 & 212 \\
\hline & Dark brown & Glomus constrictum & $133 \pm 30 \mu \mathrm{m}$ & 12 & \\
\hline \multirow{4}{*}{ L.creticus + R.monosperma } & Dark brown & Glomus constrictum & $150 \pm 20 \mu \mathrm{m}$ & 18 & 102 \\
\hline & Brown & Acaulospora tuberculata & $156 \pm 10 \mu \mathrm{m}$ & 80 & \\
\hline & Big light brown & Claroideoglomus lamellosum & $140 \pm 20 \mu \mathrm{m}$ & 2 & \\
\hline & Yellow hyaline & Gigaspora decipiens & $120 \pm 20 \mu \mathrm{m}$ & 2 & \\
\hline \multirow{3}{*}{ Bare soil } & Dark brown & Glomus constrictum & $133 \pm 30 \mu \mathrm{m}$ & $>5$ & $>10$ \\
\hline & Deep orange & Glomus aurantium & $100 \pm 30 \mu \mathrm{m}$ & $>5$ & \\
\hline & Brown & Non identified & $156 \pm 10 \mu \mathrm{m}$ & $>5$ & \\
\hline
\end{tabular}

The number of spores is due to their formation, degradation and germination processes. The maximum spore density is reached in springtime (Smith, 1980). According to Abbas et al. (2006); Nicolson (1960) the factors that affect the distribution of AMF in the dunes are the vegetable cover, the degree of stability, the amount of organic matter and the micro-biological activity.

Depending on diversity, characterized by shape, color and size of the spores, we have noted the presence of 6 genera: Glomus, Acaulospora, Gigaspora, Claroideoglomus, two kinds of spores have not been identified. We have also observed that the genera Glomus and Acaulospora are the most abundant in these types of soil (Figure 4). These results are in accordance with those found by Bouazza et al. (2015); Nehila (2016) along the Algerian coastline as well as those recorded in the coastal dunes of Spain in the work of Camprubí et al. (2010). They were all able to identify only 3 genera including Glomus, Scutellospora, Gigaspora and Glomus being the most abundant. As was observed in their findings, it seems that the kind Glomus is the most ubiquitous thanks to its aptitude to adapt to the drastic environmental conditions such as the dryness and salinity of the soil (Błaszkowski et al., 2002).

Despite the fact that L. creticus is the richest in number of spores produced, it contains the least diversity (2 morphotypes). Conversely, $R$. monosperma contains the largest diversity of AMF spores but fewer in count (Table 3). This means that the vegetable species controls the quantity and quality of AMF. 

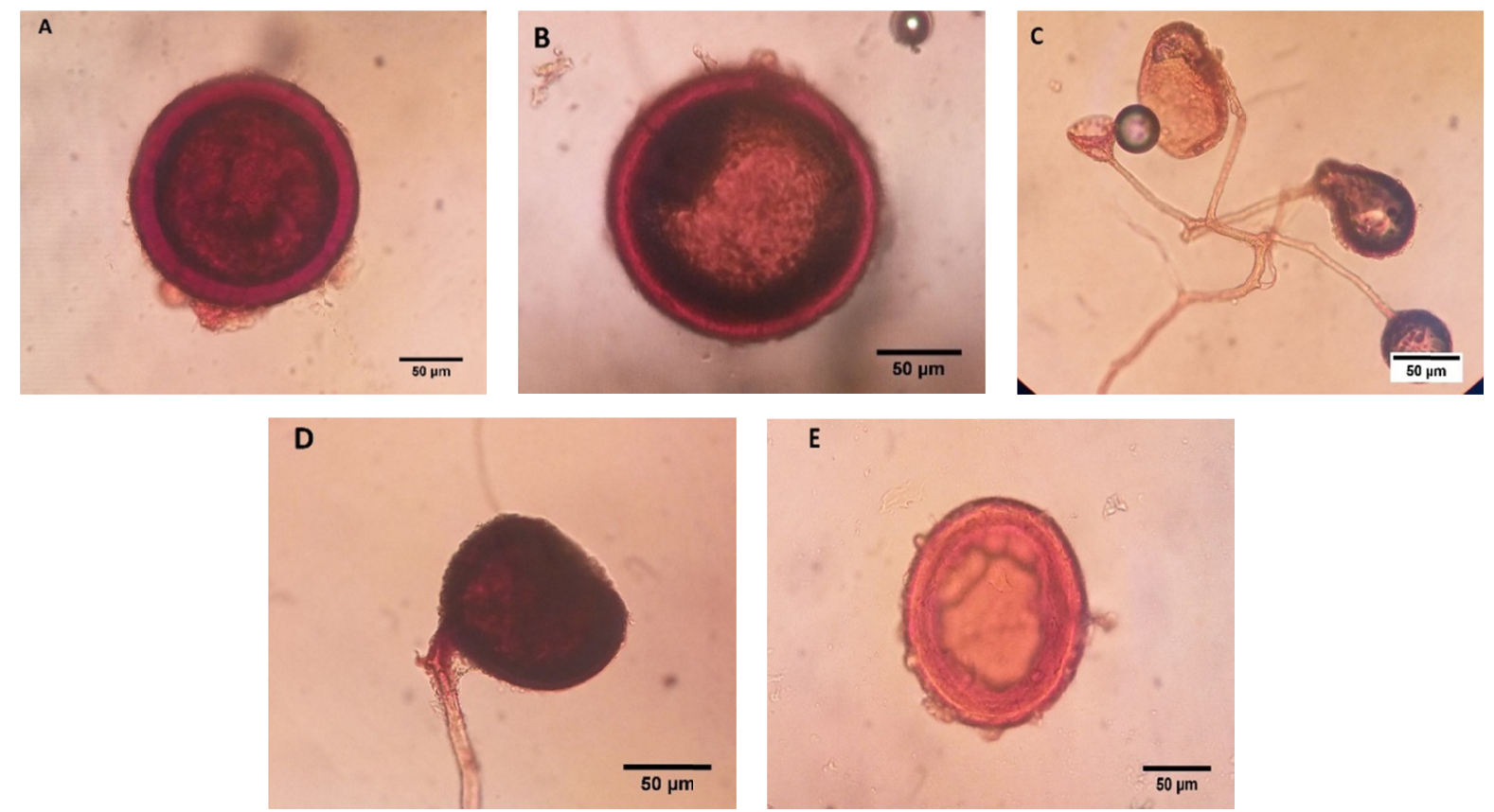

Figure 3. AMF spores in PVLG + Melzer's reagent. A: Glomus constrictum; B: Acaulospora tuberculata; C: Glomus aggregatum; D: Non identified; E: Claroideoglomus lamellosum

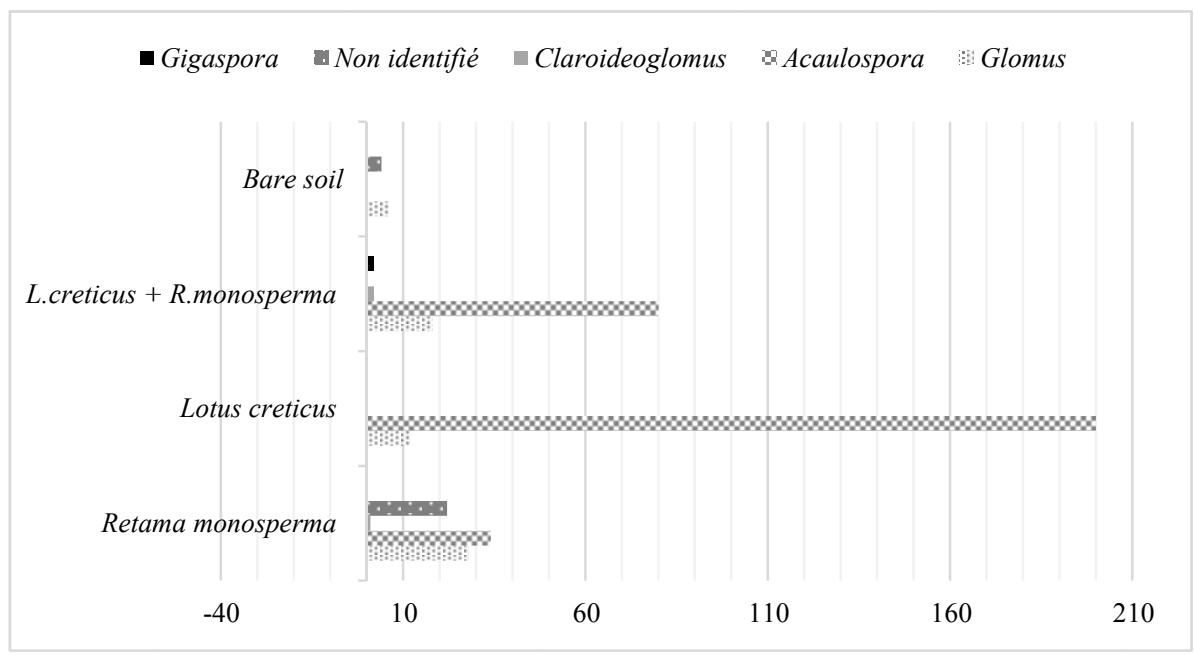

Figure 4. Endomycorrhizal frequency distribution on soil of leguminous plants

\subsection{Principal Component Analysis PCA}

The principal component analysis (PCA) allows for a graphic representation of the growth factors of the carob tree and the microbiological factors including AMF and bacterial count. The two axes describe $79 \%$ of the total variation. The first axis expresses the highest rate of variation (55.2\%). It is positively correlated with areal weight, fresh weight, branch number dry weight, leaf number, root weight root length and nitrogen level. It is negatively correlated with spore diversity, spore number, frequency, intensity and arbuscular rate of mycorrhizal fungi as well as with UFC bacteria and UFC actinobacteria, aerial length and phosphorus level. The second axis represents $23.47 \%$ of information. It is positively correlated with nitrogen level, root length, root weight, leaf number, branch number, fresh weight, spore number, spore diversity, UFC bacteria intensity and arbuscular mycorrhizal fungi rate. It is negatively correlated with phosphorus level, aerial length, dry weight, aerial weight, UFC actinobacteria and mycorrhizal fungi frequency (Figure 5). 

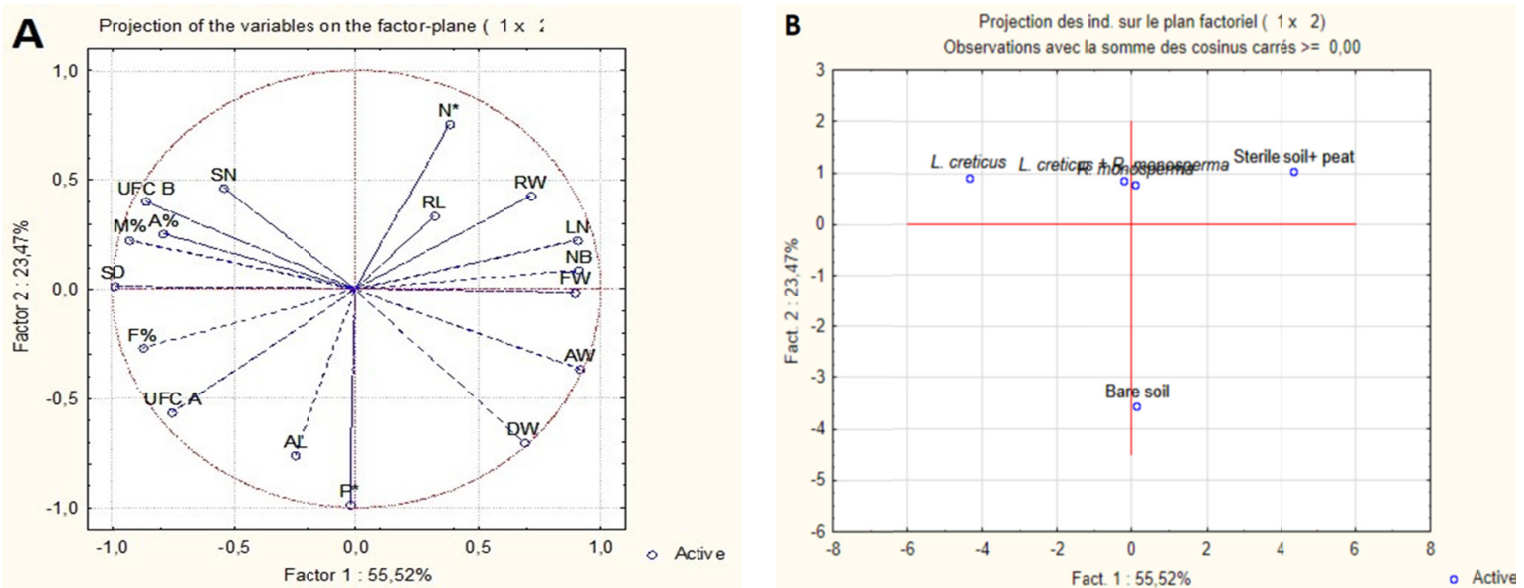

Figure 5. Principal components analysis with traits recorded on growth parameters of carob tree planted in different soils and the microbiological parameters on the first two PCA axis. A: Contribution of traits to the first two PCA axes. B: Distribution of soils to the first two PCA axes

Note. RL: root length; RW: root weight; LN: leaves number; NB: number of branches; FW: fresh weight; Aw: areal weight; DW: dry weight; AL: Areal length; SN: spore number; SD: spore diversity; UFCB: UFC bacteria; UFCA: UFC actinobacteria; F\%: frequency of AMF; M\%: intensity of AMF; A\%: Arbuscules of AMF.

There is a negative correlation between growth parameters including dry weight, areal weight, fresh weight, number of branches, leaves number, root weight, root length and the microbiological parameters including bacterial count, sporal count and diversity and mycorrhization level F\%, M\%, A\%. Although AMF differ in their ability to influence the plants' growth according to John (2003); Kiers et al. (2000); Sanders and Fitter (1992) even with the same AMF, there cannot be a positive effect on all the plants. Contrary to many studies, according to Amir et al. (2019); Raklami et al. (2019) who show the beneficial effect of AMF on the plant and their role in the improvement of its nutrition, growth and its resistance to pathogenic agents and abiotic stress.

According to O'Neill et al. (1991) mycorrhizal association is complex and hierarchical, and the plant growth varies depending on whether the response is positive (mutualism), neutral (commensalism) or even negative (parasitism). Therefore, symbiosis should be more precisely defined as a parasitism to a mutualism continuum (John, 2003; Johnson et al., 1997).

On the other hand, PCA carried out on the recorded traits showed a weak and negative colonization response of AMF on the carob tree. These results have been observed with wheat and barley in the work of Campos et al. (2018); Hetrick et al. (1996). This could be due to an imbalance in the exchange of nutrients especially through the primary interaction stage of AMF and plant (Dickson et al., 1999). The regress in growth after colonization by AMF is normally attributed to an excess of photosyntate shared with the fungi partner, which would represent up to $20 \%$ of the carbon fixed by the host plant (Campos et al., 2018; Jakobsen, 1995; Morgan et al., 2005; Ortas et al., 2002). This effect is controlled by genotype and biotic and abiotic environments according to Melanie (2004). These parameters control the diverse positions that AMF may occupy ranging from parasitism to mutualism.

Analysis of PCA also demonstrates the existence of a positive correlation between the microbiological parameters through bacterial UFC and the mycorrhization factors including mycorrhyzation rate (F, M, A\%), sporal diversity and number. These parameters are characteristic of L. creticus soil that is rich in mycorrhizal spores and in bacterial UFC. This species has been used in Spain to fix dunes in the Spanish coast and is considered a pioneer plant in the enhancement of the soil structure and as a symbiotic inoculum provider for the succession of future coming plants (Escaray et al., 2010). This correlation is in accordance with the study of Tibbett et al. (2008) concerning mycorrhization factors in which it is observed that the increase in diversity of AMF in Lotus pedunculatus and Lotus australis is correlated with the level and frequency of colonization by AMF.

Thus some Lotus sp. plants associated with other herbaceous plants are the result of the increase of concentration of $\mathrm{P}$ and $\mathrm{N}$ in the tissues of the latter (Escaray et al., 2011; Garcia et al., 2008). The findings of this research disagree with our results as $L$. creticus has not influenced the carob tree growth via its rhizospheric flora and even has a negative effect on their $\mathrm{P}$ and $\mathrm{N}$ assimilation. This may be due to incompatibility of rhizospheric 
micro-organisms with the carob tree; in fact, they are possibly even considered as deleterious micro-organisms (DRMO). It may be due to deleterious rhizo-bacteria (DRB) or fungi as it was shown by Schippers et al. (1986); Suslow and Schroth (1982).

The level of $\mathrm{P}$ and the aerial length present a positive correlation as well as the frequency of mycorhization and the number of actinobacteria which characterize bare soil. The rise of the level of $\mathrm{P}$ in the leaves is due to good phosphorus assimilation in the soil through the ability of microbes to solubilize phosphates (otherwise insoluble in metallic complexes or in hydroxyapatite) and to release them (Rodriguez \& Fraga, 1999), in this case actinobacteria which present a positive correlation with the level of phosphorus.

As reported by Franco-Correaa et al. (2010); Hamdali et al. (2008); Oliveira et al. (2009) actinobacteria such as Streptomyces, Micrococcus, Micromonospora, Kitasatospora and Thermobifida have the capacity to solubilize phosphates. They enhance the plant's growth through production of siderophore as a solubilization mechanism. Siderophore chelation of phosphoric absorbent like aluminum, iron and calcium increases solubilization of phosphates (Hamdali et al., 2008). These observations explain why the soil, rich in actinobacteria, has a beneficial effect on the growth of the upper aerial part of the plant.

PCA analysis also reveals that substrate with peat (sterile soil + peat) has a positive effect on the increase of N level in the leaves and improves the growth parameters of the root and aerial parts. Therefore, there is a positive correlation between root length, root weight, leaves number, branch number and fresh weight on the one hand, and sterile soil + peat on the other. This is probably due to peat which serves as an adjuvant, rich in nutrients for the plant, and to its beneficial physical properties and great exchange capacity of nutrients, particularly $\mathrm{N}$ and $\mathrm{P}$ (De Kreij \& Van Leeuwen, 2001; Raviv et al., 1986). Nonetheless, sterile soil + peat does not positively correlate with aerial length, although certain studies like that of Zaller (2006) demonstrate that in the case of certain varieties of tomato, commercial peat has a positive effect on elongation, therefore on aerial length.

\section{Conclusion}

As far as the carob tree is concerned, the spontaneous leguminous plants L. criticus, $R$. monosperma and the association L. creticus and R. monosperma, cannot be used as nurse plants. They do not help and even impair its growth, through the effect of their rhizospheric microsymbionts (bacteria, actinobacteria and endomycorrhizal fungi). However, sterile soil added to peat has a positive impact on the growth of the tree and its mineral nutrition in nitrogen. Moreover, actinobacteria are widespread in bare soil and have an impact on phosphorus uptake.

Thus, in order to implement a reforestation program by the carob tree in the soil and climatic conditions of the region, it is sound to select the most efficient actinobacteria strains in phosphorus solubilization. The use of peat as a substrate improves the tree's nutrition in nitrogen. This combination may therefore be used as a biofertilizer.

\section{Acknowledgements}

We would like to express our appreciation to the Reforestation Team of the sand quary of Terga and its Director, $\mathrm{Mr}$ B.Bellemou for their active particpation in the study, our special thanks to Mr A.Bouraoui for his logistic backup, and to the LTPO of Oran and Tlemcen for their assistance in the physical and chemical analyses of the soil. Our thanks equally go to Mr K.Dalli for his linguistic guidance.

\section{References}

Abbas, Y., Ducousso, M., Abourouh, M., Azcón, R., \& Duponnois, R. (2006). Diversity of arbuscular mycorrhizal fungi in Tetraclinis articulata (Vahl) Masters Woodlands in Morocco. Ann For Sci, 63, 285-291. https://doi.org/10.1051/forest:2006007

AFNOR. (1990). Granulats, analyse granulométrique par tamisage Norme (pp. 18-560).

Agate, A. D., \& Bhat, J. V. (1963). A method for the preferential isolation of actinomycetes from soils. Antonie Van Leeuvenhoek, 29, 297-304. https://doi.org/10.1007/BF02046072

Ait Chitt, M., Belmir, H., \& Lazrak, A. (2007). Production de plants sélectionnés et greffés de caroubier. Bulletin mensuel d'information et de liaison du PNTTA ( ${ }^{\circ}$ 153). Transfert de technologie en agriculture, MAPM/DERD.

Albaladejo, J., Martinez-Mena, M., Roldan, A., \& Castillo, V. (1988). Soil degradation and desertification induced by vegetation removal in semiarid environment. Soil Use Manag, 14, 1-5. https://doi.org/ $10.1111 / \mathrm{j} .1475-2743.1998 . t b 00602 . x$ 
Amir, H., Cavaloc, Y., Laurent, A., Pagand, P., Gunkel, P., Lemestre, M., .. McCoy, S. (2019). Arbuscular mycorrhizal fungi and sewage sludge enhance growth and adaptation of Metrosideros laurifolia on ultramafic soil in New Caledonia: A field experiment. Science of the Total Environment, 651, 334-343. https://doi.org/10.1016/j.scitotenv.2018.09.153

Anne, P. (1945). The rapid assay of organic carbon in soils (2nd Ann. Agroni. April, May, June, 1945, 5HE).

Azcon-Aguilar, C., Palenzuela, J., Roldan, A., Bautist, S., Vallejo, R., \& Barea, J. (2003). Analysis of the mycorrhizal potential in the rhizosphere of representative plant species from desertification-threatened Mediterranean shrub lands. Appl. Soil Ecol., 22, 29-37. https://doi.org/10.1016/S0929-1393(02)00107-5

Batlle, I., \& Tous, J. (1997). Carob tree Ceratonia siliqua L. International Plant Genetic Resources Institute, Rome.

Belechheb, T., Bakkali, M., Laglaoui, A., \& Arakrak, A. (2016). Mycorrhizal Fungi Status Associated with the Rhizosphere of Cytisus monspessulanus in the North West of Morocco. International Journal of Pure \& Applied Bioscience, 4(6), 1-8. https://doi.org/10.18782/2320-7051.2427

Bencherif, K., Boutekrabt, A., Dalpé, Y., \& Hadj Sahraoui, A. L. (2016). Soil and seasons affect arbuscular mycorrhizal fungi associated with Tamarix rhizosphere in arid and semi-arid steppes. Applied Soil Ecology, 107, 182-190. https://doi.org/10.1016/j.apsoil.2016.06.003

Benlhadj, D. S., Ighilhariz, Z., Boukhatem, Z. F., Duponnois, R., De Lajudie, P., \& Bekki, A. (2016). Plant soil symbioses, role in Terga (West of Algeria) sandpit rehabilitation. International Journal of Biosciences, 9, 148-161.

Bever, J. D., Dickie, I. A., Facelli, E., Facelli, J. M., Klironomos, J. N., Moora, M., ... Zobel, M. (2010). Rooting theories of plant community ecology in microbial interactions. Trends in Ecology \& Evolution, 25, 468-478. https://doi.org/10.1016/j.tree.2010.05.004

Blaskowski, J. (2018). Arbuscular mycorrhizal fungi (Glomeromycota), endogone and complexipes species deposited in the Department of Plant Pathology, University of Agriculture in Szczecin, Poland. Retrieved from http:/www.zor.zut.edu.pl/Glomeromycota/index.html

Błaszkowski, J., Tadych, M., \& Madej, T. (2002). Arbuscular mycorrhizal fungi (Glomales, Zygomycota) of the Błedowska Desert Poland. Acta Societatis Botanicorum Poloniae, 71, 71-85. https://doi.org/10.5586/ asbp.2002.008

Bouazza, M., K., Ighilhariz, Z., de Lajudie, P., Duponnois, R., \& Bekki, A. (2015). Assessing the Native Arbuscular Mycorrhizal Symbioses to Rehabilitate a Degraded Coastal Sand Dune in Algeria. IJACS, 194-202.

Brunel, B. (2006). La microbiologie des sols: Un champ prometteur pour l'agro-écologie. Pour une gestion intégrée et durable de la production agricole en France Paris: Club Demeter.

Campos, P., Borie, F., Cornejo, P., López-Ráez, J., López-García, Á., \& Seguel, A. (2018). Phosphorus Acquisition Efficiency Related to Root Traits: Is Mycorrhizal Symbiosis a Key Factor to Wheat and Barley Cropping? Frontiers in Plant Science, 9, 752. https://doi.org/10.3389/fpls.2018.00752

Camprubí, A., Calvet, C., Cabot, P., Piet, M., \& Estaún, V. (2010). Arbuscular mycorrhizal fungi associated with psammophilic vegetation in Mediterranean coastal sand dunes. Spanish Journal of Agricultural Research, S96-S102. https://doi.org/10.5424/sjar/201008S1-1227

Carrillo, G. A., Bashan, Y., \& Bethlenfalvay, G. J. (2000). Resource island soils and the survival of the giant cactus cardon, of Baja California. Plant Soil, 218(1-2), 207-214. https://doi.org/10.1023/A:1014953028163

De Kreij, C., \& Van Leeuwen, G. J. (2001). Growth of pot plants in treated coir dust as compared to peat. Soil Science and Plant Analysis, 32(13-14), 2255-2265. https://doi.org/10.1081/CSS-120000281

Denis, D. (2013). Le sable, enquete sur une disparition. In ARTE.

Dickson, S., Smith, S., \& Smith, F. (1999). Characterization of two arbuscular mycorrhizal fungi in symbiosis with Allium porrum: colonization, plant growth and phosphate uptake. New Phytol, 144, $163-172$. https://doi.org/10.1046/j.1469-8137.1999.00493.x

Drouineau, G. (1942). Rapid determination of the active limestone sols. Ann. Agron., 12.

Duponnois, R. B., Prin, Y., \& Baudoin, E. G., \& Dreyfus, B. (2010). Les champignons mycorhiziens: une composante majeure dans les processus biologiques régissant la stabilité et la productivité des écosystèmes 
forestiers tropicaux. Le projet majeur africain de la Grande Muraille Verte: Concepts et mise en oeuvre. Marseille, France.

El-Nakeeb, M., \& Lechevalier, H. (1963). Selective Isolation of Aerobic Actinomycetes. Appl Microbiol, 11, 75-77.

Escaray, F. J., Menendez, A. B., Gárriz, A., Pieckenstain, F. L., Estrella, M. J., Castagno, L. N., ... Ruiz, O. A. (2011). Ecological and agronomic importance of the plant genus Lotus. Its application in grassland sustainability and the amelioration of constrained and contaminated soils. Plant Science, 182, 121-133. https://doi.org/10.1016/j.plantsci.2011.03.016

Escaray, F. J., Rosique, F. J. C., Scambato, A. A., Bilenca, D., Carrasco, P., Matarredona, A. V., ... Menéndez, A. B. (2010). Evaluation of a technical revegetation action performed on foredunes at Devesa de la Albufera, Valencia, Spain. Land Degrad. Dev., 21, 239-247. https://doi.org/10.1002/1dr.970

Essahibi, A., Benhiba, L., Ait babram, M., Ghoulam, C., \& Qaddoury, A. (2017). Influence of arbuscular mycorrhizal fungi on the functional mechanisms associated with drought tolerance in carob (Ceratonia siliqua L.). Trees, 32(1), 87-97. https://doi.org/10.1007/s00468-017-1613-8

Franco-Correaa, M., Quintanaa, A., Duquea, C., Suareza, C., Rodrígueza, M., \& Bareab, J. (2010). Evaluation of actinomycete strains for key traits related with plant growth promotion and mycorrhiza helping activities. Appl Soil Ecol, 45, 209-217. https://doi.org/10.1016/j.apsoil.2010.04.007

Garcia, I., Mendoza, R., \& Pomar, M. C. (2008). Deficit and Excess of Soil Water Impact on Plant Growth of Lotus tenuis by Affecting Nutrient Uptake and Arbuscular Mycorrhizal Symbiosis. Springer, Dordrecht, PAYS-BAS. https://doi.org/10.1007/s11104-007-9526-8

Garner, W. A., \& Steinberger, Y. (1989). A proposed mechanism for the formation of fertile islands in the desert ecosystem. J. Arid Environ, 16. https://doi.org/10.1016/S0140-1963(18)30941-8

Gerdemann, J., \& Nicolson, T. (1963). pores of mycorrhizalendogone species extracted form soil by wet sieving and decanting. Trans. Br. Mycol. Soc., 46, 235-244. https://doi.org/10.1016/S0007-1536(63)80079-0

Hamdali, H., Bouizgarne, B., Hafidi, M., Lebrihi, A., Virolle, M. J., \& Ouhdouch, Y. (2008). Screening for rock phosphate solubilizing actinomycetes from Moroccan phosphate mines. Appl Soil Ecol, 38, 12-19. https://doi.org/10.1016/j.apsoil.2007.08.007

Hatimi, A., \& Tahrouch, S. (2007). Caractérisations chimique, botanique et microbiologique du sol des dunes littorales du Souss-Massa. Biomatec Echo, 2(5), 85-97.

Hetrick, B. A. D., Wilson, G. W. T., \& Todd, T. C. (1996). Mycorrhizal response in wheat cultivars: Relationship to phosphorus. Can. J. Bot., 74, 19-25. https://doi.org/10.1139/b96-003

INVAM. (2018). International culture collection of vesicular arbuscular mycorrhizal fungi. Retrieved from https://invam.wvu.edu

Jakobsen, I. (1995). Transport of phosphorus and carbon in VA mycorrhizas. Berlin: Springer. https://doi.org/ 10.1007/978-3-662-08897-5_14

John, N. K. (2003). Variation in plant response to native and exotic arbuscular mycorrhizal fungi. Ecology, 84(9), 2292-2301. https://doi.org/10.1890/02-0413

Johnson, N. C., Graham, J. H., \& Smith, F. A. (1997). Functioning of mycorrhizal associations along the mutualism parasitism continuum. New Phytologist, 135, 575-586. https://doi.org/10.1046/j.1469-8137. 1997.00729.x

Khater, C. (2004). Dynamiques végétales post-perturbations sur les carrières calcaires au Liban. Stratégies pour l'écologie de la restauration en régions Méditerranéennes (Doctorat, Université Montpellier II).

Kiers, E. T., Lovelock, C. E., Krueger, E. L., \& Herre, E. A. (2000). Differential effects of tropical arbuscular mycorrhizal fungal inocula on root colonization and tree seedling growth: Implications for tropical forest diversity. Ecology Letters, 3(2), 106-113. https://doi.org/10.1046/j.1461-0248.2000.00126.x

Kjeldahl, J. (1883). Neue Methode zur Bestimmung des Stickstof fs in organischen Körpern. Z. Anal. Chem., 22, 366-382. https://doi.org/10.1007/BF01338151

Le Roux, C. (2002). La réhabilitation des mines et carrières à ciel ouvert. Bois For Trop, 272. 
Lozano, Y. M., Hortal, S., Armas, C., \& Pugnaire, F. I. (2014). Interactions among soil, plants, and microorganisms drive secondary succession in a dry environment. Soil Biology and Biochemistry, 298-306. https://doi.org/10.1016/j.soilbio.2014.08.007

Maestre, F. T., Callaway, R. M., Valandares, F., \& Lortie, C. J. (2009). Refering the stress gradient hypothesis for competition and facilititation in plant communities. Journal of Ecology, 97. https://doi.org/10.1111/ j.1365-2745.2008.01476.x

Mahdad, M. Y., \& Gaouar, S. B. S. (2016). Le caroubier (Ceratonia siliqua L.) dans le nord ouest de l'Algerie situation et perspectives d'amélioration.

Makhzoumi, J. M. (1997). The changing role of rural landscapes: olive and carob multi-use tree plantations in the semiarid Mediterranean. Landscape and Urban Planning, 37(1), 115-122. https://doi.org/10.1016/ S0169-2046(96)00376-3

Melanie, D. J., \& Smith, S. E. (2004). Exploring functional definitions of mycorrhizas: Are mycorrhizas always mutualisms? Can. J. Bot., 82, 1089-1109. https://doi.org/10.1139/b04-110

Morgan, J. A., Bending, G. D., \& White, P. J. (2005). Biological costs and benefits to plant-microbe interactions in the rhizosphere. J. Exp. Bot., 56, 1729-1739. https://doi.org/10.1093/jxb/eri205

Mosbah, M., De Lajudie, P., \& Mars, M. (2018). Molecular identification of arbuscular mycorrhizal fungal spores associated to the rhizosphere of Retama raetam in Tunisia. Soil Science and Plant Nutrition, 64(3), 335-341. https://doi.org/10.1080/00380768.2018.1431012

Nehila, A. (2016). symbiose telluriques: Role et mécanisme de Tolérance aux stress abiotiques. Doctorat LMD, Université Ahmed Ben Bella Oran1.

Nehila, A., Ighilhariz, Z., Boukhatem, Z. F., \& Bekki, A. (2015). Diversity of Arbuscular Mycorrhizal fungi in two perturbed ecosystems (dune and saline soil) in west Algeria. IJACS, 380-387.

Nicolson, T. (1960). Mycorrhiza in the gramineae. Developpement in different habitats, particularly sand dunes. Trans. Br. Mycol. Soc, 43(1), 132-145. https://doi.org/10.1016/S0007-1536(60)80017-4

O’Neill, E., O’Neill, R., \& Norby, R. (1991). Hierarchy theory as a guide to mycorrhizal research on large-scale problems. Environmental Pollution, 73, 271-284. https://doi.org/10.1016/0269-7491(91)90054-Z

Oliveira, C. A., Alves, V., Marriel, I., Gomes, E., Scotti, M., Carneiro, N., ... Sa, N. (2009). Phosphate solubilizing microorganisms isolated from rhizosphere of maize cultivated in an oxisol of the Brazilian Cerrado Biome. Soil Biol Biochem, 41, 1782-1787. https://doi.org/10.1016/j.soilbio.2008.01.012

Olsen, S. R., Cole, C. V., Watanabe, F. S., \& Dean, L. A. (1954). Estimation of Available Phosphorus in Soils by Extraction With Sodium Bicarbonate (Circ. 939). U.S. Dept. Agri., Washington, DC.

Ortas, I., Ortakci, D., Kaya, Z., Cinar, A., \& Onelge, N. (2002). Mycorrhizal dependency of sour orange in relation to phosphorus and zinc nutrition. J. Plant Nutr., 25, 1263-1279. https://doi.org/10.1081/ PLN-120004387

Phillips, J., \& Hayman, D. (1970). Improved procedures for clearing roots and staining parasitic and vesicular arbuscularmycorrhizal fungi for rapid assessment of infection. Trans Br Mycol Soc, 55, 158-161. https://doi.org/10.1016/S0007-1536(70)80110-3

Raklami, A., Bechtaoui, N., Tahiri, A. I., Anli, M., Meddich, A., \& Ofdou, K. (2019). Use of Rhizobacteria and Mycorrhizae Consortium in the Open Field as a Strategy for Improving Crop Nutrition, Productivity and Soil Fertility. Front. Microbiol. https://doi.org/10.3389/fmicb.2019.01106

Rapilly, F. (1968). Techniques de mycologie en pathologie végétale. Ann. Epiphities, 19, $n^{\circ}$ Hors Série.

Raviv, M., Chen, Y., \& Inbar, Y. (1986). The use of peat and composts as growth media for container-grown plants. In Y. Chen, \& Y. Avnimelech (Eds.), The Role of Organic Matter in Modern Agriculture (pp. 257-287). Martinus Nijhoff Publ., Dordrecht. https://doi.org/10.1007/978-94-009-4426-8_11

Richer, C. (2018). Pénurie de sable en Algérie: La crise dont on ne parle pas assez, Lematin d'algerie. Retrieved from http://www.lematindalgerie.com/penurie-de-sable-en-algerie-la-crise-dont-ne-parle-pas-assez

Rinaudo, G. (1970). Fixation biologique de l"azote dans trois types de sols de rizières de Côte-d'Ivoire (Doctorat, Fac. Sci. Montpellier).

Rodriguez, H., \& Fraga, R. (1999). Phosphate solubilizing bacteria and their role in plant growth promotion. Biotechnol Adv, 17, 319-339. https://doi.org/10.1016/S0734-9750(99)00014-2 
Sanders, I. R., \& Fitter, A. H. (1992). Evidence for differential responses between host-fungus combinations of vesicular arbuscular mycorrhizas from a grassland. Mycological Research, 96, 415-419. https://doi.org/ 10.1016/S0953-7562(09)81084-8

Schippers, B., Bakker, A. W., Bakker, P. A. H. M., Weisbeek, P. J., \& Lugtenberg, B. (1986). Plant growth-inhibiting and stimulating rhizosphere microorganisms. London/New York: Elsevier Scientific.

Sharma, D., Kaur, T., Chadha, B. S., \& Manhas, R. K. (2011). Antimicrobial Activity of Actinomycetes Against Multidrug Resistant Staphylococcus aureus, E. coli and Various Other Pathogens. Tropical Journal of Pharmaceutical Research, 10, 801-808. https://doi.org/10.4314/tjpr.v10i6.14

Smith, S. E. (1980). Mycorrhizae of autotophic higher plant. Biological Reviews, 55, 475-550. https://doi.org/ 10.1111/j.1469-185X.1980.tb00701.x

Susana, R. E., Yudi, M. L., \& Richard, D. B. (2016). Mechanisms and consequences of facilitation in plant communities influence of soil microbiota in nurse plant systems. Functional Ecology, 30, 30-40. https://doi.org/10.1111/1365-2435.12594

Suslow, T. V., \& Schroth, M. N. (1982). Role of deleterious rhizobacteria as minor pathogens in reducing crop growth. Phytopathol, 72, 111-115. https://doi.org/10.1094/Phyto-72-111

Tibbett, M., Ryan, M. H., Barker, S. J., Chen, Y., Denton, M. D., Edmonds-Tibbett, T., \& Walker, C. (2008). The diversity of arbuscular mycorrhizas of selected Australian Fabaceae. Plant Biosyst, 142(2), 420-427. https://doi.org/10.1080/11263500802151124

Trouvelot, A., Kough, J., \& Gianinazzi-Pearson, V. (1986). Mesure du taux de mycorrhization d'un system radiculaire recherché de methods d'estimation ayant une signification fonctionnelle. In $\mathrm{V}$. Gianinazzi-Pearson, \& S. Gianinazzi (Eds.), Physiological and genetical aspects of mycorrhizae (pp. 217-221). INRA, Paris.

Truog, E. (1930). The determination of the readily available phosphorus of soil. Amer Soc. Agron, 874-882. https://doi.org/10.2134/agronj1930.00021962002200100008x

Tuo, D., Xu, M., \& Gao, G. (2018). Relative contributions of wind and water erosion to total soil loss and its effect on soil properties in sloping croplands of the Chinese Loess Plateau. Science of the Total Environment, 633, 1032-1040. https://doi.org/10.1016/j.scitotenv.2018.03.237

Zaller, J. G. (2006). Vermicompost as a substitute for peat in potting media: Effects on germination, biomass allocation, yields and fruit quality of three tomato varieties. Scientia Horticulturae, 191-199. https://doi.org/10.1016/j.scienta.2006.12.023

\section{Copyrights}

Copyright for this article is retained by the author(s), with first publication rights granted to the journal.

This is an open-access article distributed under the terms and conditions of the Creative Commons Attribution license (http://creativecommons.org/licenses/by/4.0/). 